\title{
P2-03
}

\section{IgG4 関連疾患および近縁疾患における形質芽細胞を標的とした新規治療の開発}

\section{○小荒田秀一，堺真梨子，貞永裕梨，丸山暁人，小野伸之，多田芳史 (佐賀大学 膠原病リウマチ内科)}

【目的】IgG4 関連疾患において形質芽細胞に関しての報告は少ない. 形質芽細胞のフェノタイプ, 分画 を鑑別を要する近縁疾患であるSLE，シェーグレン症候群，後腹膜線維症，ANCA 関連血管炎（AAV） と比較し, 各疾患における特徵を検討し, 疾患別の新規治療標的を探索する。【方法】患者由来 B 細胞 をCD19, CD138, RP105 の発現をもとに, 形質芽細胞から形質細胞に至る 5 つのサブセットに分け，200 種類以上の B 細胞関連抗原の発現についてフローサイトメトリーを用いて解析した。【結果】IgG4-RD, SLE, SS, AAV では RP105 陰性前形質芽細胞, 形質芽細胞, 後期形質芽細胞が正常と比較して増加し, 同細胞比率は疾患活動性と相関した。同細胞比は, 臟器障害数と相関した。 IgG4-RD は SLEよりも, 分画分布が，より早期の前形質芽細胞に偏っていた。 CXCR5 の発現は, SLE では, 早期に消失したが, IgG4-RD では, 後期形質芽細胞の段階まで発現が持続していた. BCMA の発現はSLE の形質芽細胞で 増加がみられた。【結論】RP105 除性形質芽細胞は, 自己免疫疾患における診断, 活動性マーカーとし て有用で, 治療標的としても重要である. 疾患に特異的な治療標的分子として, IgG4-RD では CXCR5CXCL13 ケモカイン経路が, SLEではBCMA/BAFF-R/TACI-BLyS/APRIL 経路が示唆される. 形質芽細 胞は, 自己免疫病態での治療標的として重要性が示唆されているが, 原疾患の各病態に応じた B 細胞 標的の策定が重要である. 